\title{
Childhood
}

\section{'Remembrance isn't working': First World War battlefield tours and the militarisation of British youth during the centenary}

\begin{tabular}{|r|l|}
\hline Journal: & Childhood \\
\hline Manuscript ID & CHD-19-0068.R2 \\
\hline Kanuscript Type: & Special Issue: Children, Childhoods, and Everyday Militarisms \\
\hline Abstract: & $\begin{array}{r}\text { Weywords: } \\
\text { initiative to mark the centenary of the First World War. Based on } \\
\text { empirical research conducted with pupil participants on the FWWCBTP, } \\
\text { this paper explores the processes of militarisation present within these } \\
\text { tours as well as the way young people participated in and made sense of } \\
\text { these practices. }\end{array}$ \\
\hline & \\
\hline
\end{tabular}

\section{SCHOLARONE \\ Manuscripts}




\section{'Remembrance isn't working': First World War battlefield tours and the militarisation of British youth during the centenary}

\section{Introduction}

When UK Prime Minister, David Cameron, unveiled the UK government's long-awaited plans to mark the centenary of the First World War in October 2012 he underscored how it was an opportunity to 'provide the foundations upon which to build an enduring cultural and educational legacy' putting 'young people front and centre in our commemoration' in order 'to ensure that the sacrifice and service of a hundred years ago is still remembered in a hundred years' time'. ${ }^{1}$ The cornerstone of this youth-focused commemorative activity, at a cost of $£ 5.3$ million, was the First World War Centenary Battlefield Tours Programme (FWWCBTP), delivered by UCL Institute of Education (UCL IoE) and Equity, a specialist provider of group tours for educational institutions, and designed to give the opportunity for at least two students, aged predominately 11 to 14 years old, and one teacher from every state-funded secondary school in England to visit the battlefields in a four-day tour of the major battlefields and memorial sites on the Western Front. ${ }^{2}$

The stated objectives of the FWWCBTP were to (1) enable young people to acquire a deeper understanding of the First World War based on the latest historiography and (2) create a generation who will carry the memory of the war forward (Pennell, 2018). Just over 4,500 students from 1,811 schools participated between September 2014 and March 2019 travelling in cohorts of between 80 and 120 participants per tour spread across two to three coaches. ${ }^{3}$

\footnotetext{
${ }^{1}$ See https://www.gov.uk/government/speeches/speech-at-imperial-war-museum-on-first-world-war-centenaryplans (accessed 9 July 2019).

${ }^{2}$ It is worth noting that the FWWCBTP worked with schools from England only. This could be interpreted as being in contradiction to official government claims of a 'truly national commemoration' of the war. See Mycock (2014).

${ }^{3}$ Statistics provided by FWWCBTP Programme Director via email to author, 11 July 2019. For more information on the programme, see https://www.centenarybattlefieldtours.org/about-us/ (accessed 9 July 2019).
} 
Each coach was led by an accredited International Guild of Battlefield Guide (GBG) accompanied by a serving soldier and a member of Equity staff. Each tour was supported by a senior member of the FWWCBTP UCL IoE team as well as a mobile team of senior army officers who were there, primarily, to support their junior personnel (Pennell, 2018). While primarily funded by the Department for Education (DfE) and Department for Communities and Local Government (DCLG) ${ }^{4}$ it was supported by the Ministry of Defence (MoD) as part of its broader mission to mark the centenary of the First World War and the British army's participation in the conflict, Operation REFLECT (Foley, 2014). ${ }^{5}$ The tours were deemed highly successful winning various educational and youth travel awards and receiving commendations from both participating teachers and key British politicians, including the Chancellor of the Exchequer who, in the October 2018 budget, renewed funding until $2020 .^{6}$

This article seeks to build on existing literature on war remembrance, national identity, and militarisation to explore the processes of militarisation present within these tours and the way the young participants participated in, understood and resisted these practices. It is based on data gathered via survey, verbal, elicitation and observational approaches (Hopkins, 2010) with 1,016 young people who travelled on the spring tours between 2015 and $2017 .{ }^{7}$ The

\footnotetext{
${ }^{4}$ In January 2018, as part of a Cabinet reshuffle, it was announced that the DCLG would be renamed the Ministry of Housing, Communities and Local Government (MHCLG). See https://www.gov.uk/government/news/government-renews-focus-on-housing-with-ministry-of-housingcommunities-and-local-government (accessed 9 July 2019).

${ }_{5}^{5}$ Aside from (now broken) webpages (see www.army.mod.uk/training education/25813) accessed via Internet Archive Wayback Machine (https://archive.org/web/), little additional information about the MoD's 'First World War Support to Schools' scheme was available publicly. A Freedom of Information (FOI) request was largely refused under Section 12 (cost limits). In addition, the centenary in the UK was a cross-government initiative involving the DfE, DCLG and the Department for Digital, Culture, Media and Sport (DCMS) as well as the $\mathrm{MoD}$, which resulted in questions about funding and delivery being obfuscated. Letter from Army Secretariat, Army Headquarters to author in response to a request for information under the Freedom of Information Act 2000, 18 June 2019 (Ref: FOI2019/05925).

${ }^{6}$ Letter on impact of the programme from FWWCBTP Programme Director to author, 7 March 2019. See also https://www.gov.uk/government/speeches/budget-2018-philip-hammonds-speech (accessed 17 July 2019).

${ }^{7}$ A mixed methods approach was adopted owing to its recognised benefits, particularly within education research, as a means to get deeper and broader insights, and to validate findings in research projects of this nature (Bernhard, 2019). For a detailed critical reflection on the methods employed in this project, in comparison to a similar study in New Zealand, see Pennell and Sheehan (2020).
} 
tours are interpreted as a space where cultural elites (a government funded programme) have determined the common narratives about Britain's engagement in the First World War and the nation-state's identity as a security actor within a broader world order (Reeves, 2018). Working with Enloe's core tenets of militarism, notably that war is necessary and purposeful, with having enemies being a natural condition; violence is normal; the soldier is to be glorified (Enloe, 2004: 219; see also Bernazzoli and Flint, 2009: 400-401), this article explores the tensions within these tours between celebrating British armed service and highlighting the tragic cost of war and, most importantly, considers the ways young people involved made sense of this, as acting subjects in their own right rather than passive objects or recipients of remembrance practices. Focus will concentrate on three primary sites of interaction: on the battlefields of the Somme; with the artefacts of and memorials to violent industrialised warfare; and with serving soldiers of the British army. In response to the broader mission of Critical Military Studies to be 'sceptically curious' (Basham et al, 2015: 1) and in line with Hyde's (2016) illumination of the contradictions and confusion within the everyday lived experience of militarisation, it will highlight the way that government sponsored tours to the Western Front during the centenary of the First World War are far from straightforward spaces of militarisation.

\section{Militarism, Remembrance and Youth}

Militarism and militarisation is understood in this article as a process through which military objectives and priorities extend into civilian life (Enloe, 2000; Jenkings et al, 2012;

Woodward, 2004) as part of a Gramscian notion of hegemony whereby support, or at least acquiescence, for a large standing army and its associated activities must be contrived from those who do not necessarily have a stake in the well-being of this institution (Bernazzoli and Flint, 2009). Those who study the process of militarisation note its social (involving people 
and their understandings and responses) and spatial (occurring in specific places) characteristics. As militarisation is often seen as 'an intentional, sustained and deliberate practice on the part of state military institutions and wider actors supportive of state objectives' (Jenkings et al, 2012: 357) a number of scholars take the UK's enthusiastic stateled commemoration of past conflicts (particularly the First and Second World Wars) as compelling evidence of the way 'the military has invaded every part of our lives' (Bourke, 2014: 2; Enloe, 1983, 2004, 2007). Acts of remembrance are one of the key ways 'populations come to understand and react to military institutions, practices, power and force' (Basham, 2016: 884). It is within these ceremonies that the intersections of militarism with patriotism, nationalism and religion (notably Anglican Christianity) are most clearly on display, as are the ways national elites and everyday citizens engage in the glorification of the soldier (Bernazzoli and Flint, 2009) accepting war as a regrettable but necessary sacrifice (Basham, 2016). For societies to be mobilised into conflicts, they have to understand a certain set of ideas about nation, identity, enemies and obligations (Stern, 1995) and there exists a rich scholarship on the multifaceted ways sites of war remembrance circulate and reproduce ideas about national identity (Ashplant et al, 2000; Gillis, 1994; Hutchinson, 2007; Reeves, 2018).

In answer to Enloe's call to activate 'critical curiosities about ideas, practices and sites that might seem less obvious' (Enloe, 2004; Beier, 2011: 3) increasing attention is being paid to the subtle and indirect forms of militarisation that shape the everyday lives of children within and beyond zones of conflict, particularly in the global north and so-called post-conflict or peaceful societies (Solomon and Denov, 2010). Scholars have explored the ways militarism might be experienced, felt or engaged with in childhood, such as in the school curricula, museums, toys, films and video games (Carter et al, 2006; Doucet, 2005; Gor, 2003; 
Hörschelmann, 2016; MacDonald, 2008; Power, 2007; Reagan, 1994; Shaw, 2010) as well as the relationship between militarism, childhood and recruitment to the armed forces (Rech, 2014, 2016; Wells, 2014). However, while debates about war remembrance and the spaces they occupy, the performances they invoke, and the people they involve are central to understanding processes of militarisation, the involvement of children and young people in these commemorative practices, and their responses to them, has received less attention (Benwell and Hopkins, 2016). This article seeks to address the dearth in the literature by capturing children as acting subjects in this social space and, by extension, argue that children, young people, the figure or imaginary of the child, and varied youthful engagements are inherent to contemporary discourses and practices of remembrance, not simply incidental.

\section{Britain's necessary war?}

Martin Shaw (1991) defines militarism in contemporary British culture in relation to 'the national military myth' founded upon 'an ideology and imagery of a totalitarian military threat, the belief that 'appeasing' such threats is wrong, and that military strength is the foundation of security' (Shaw, 1991: 119). The UK government's approach to the centenary commemorations of the First World War were imbibed by these ideas; in January 2014, Michael Gove - then Secretary of State for Education - publicly argued that left-wing historians and television programmes had denigrated 'patriotism and courage by depicting the war as a "misbegotten shambles", when, in fact, it was "plainly a just war to combat aggression by a German elite bent on domination' (Shipman, 2014).

To some extent, the tour content fuelled ideas of the war's necessity (and by default an uncritical acceptance of Germany's position as 'the enemy') because of the nature of its conception in the broader centenary context; the very choice of designing and delivering an educational and commemorative programme around a significant British military victory 
meant that issues of defeat, weakness, appeasement and opposition to war were largely irrelevant. As such, in both 2015 and 2017, the students interpreted the purpose of the tours primarily to (1) remember the dead and (2) learn about British history. ${ }^{8}$ Owing to limits of time, particular topics were chosen, to the exclusion of others, as focus for the daily enquiry questions (Pennell, 2018)..$^{9}$ As a result, discussions of why Britain entered the war (or whether it should have) were largely absent in favour of focus on the everyday experience of being at war (Enquiry Question 1) and the significance of remembrance in the modern era (Enquiry Question 3).

The second Enquiry Question was explored during a day's visit to the Somme battlefields in France and invited students to consider whether the four-month offensive in 1916, which resulted in over a million casualties, was a disaster (Bendry, 2017). Various pedagogical tools, including map-reading, topography, and, in 2017, a role play exercise (where pupils reenacted the experiences at 'Sunken Lane' on 1 July 1916 of members of $29^{\text {th }}$ Division $1^{\text {st }}$ Battalion Lancashire Fusiliers who were annihilated by oncoming machine-gun fire) were employed to encourage reflection on the purpose, experience and implications of the battle. The students' engagement with the question was framed by an introductory DVD, The Somme: From Defeat to Victory (BBC, 2006), shown on the coach during the drive from the hotel to the battlefield, and interjections from the GBG which combined to infer that the British army learnt crucial lessons at the Somme that enabled them to 'defeat their German enemy' ${ }^{10}$ and win the overall war on the Western Front in 1918. Linguistic demarcations of

\footnotetext{
${ }^{8}$ Survey results, 2015 and 2017.

${ }^{9}$ Enquiry questions are an important pedagogical tool used to plan quality learning in history (Riley, 2000). Through using evidence to investigate historical questions, students are given the opportunity to see that history is not just a collection of facts, but rather a rigorously constructed set of arguments. ${ }^{10}$ Quotation taken from BBC documentary The Somme: From Defeat to Victory (2006).
} 
'us' (the British) and 'them' (the Germans) were often part of the presentations employed to explain military positions across the terrain.

Students were split over attempts to introduce them to recent historiography on the topic, encapsulated by Gary Sheffield's Forgotten Victory: The First World War Myths and Realities $(2001 ; 2018)$. In both 2015 and 2017, over 50\% of survey respondents either remained indecisive or agreed/strongly agreed with the statement 'I now think the First World War was pointless'. A 2017 elicitation task undertaken the evening after the morning's role play at Sunken Lane resulted in equal numbers of responses being placed on the 'yes' and 'no' sections of a 'judgement line' in response to the question 'Was the Somme really a disaster?' One Year 10 pupil stated clearly that they felt 'the purpose of the trip is trying to give a feeling of anti-war kind of thing' and that the tour had confirmed for them that the First World War was pointless. However, another disagreed explaining that 'if we had never did challenge Germany [sic], Germany would have had the confidence to...bully other nations, of course you know a lot of men died but I think when you try to think about it, they did die for a good reason. ${ }^{11}$ By 2017, in the context of Britain's vote to leave the European Union in the referendum the previous year, one Year 10 student found the tour had galvanised his belief in Britain's detachment from the continent and implored the government to 'go for Brexit the fastest [sic] you can...It is our duty to keep the world safe and ensure good morals are applied everywhere. We're the only ones that can'. ${ }^{12}$

Explicitly nationalist perspectives, however, were rare as the nature of the tour, with its focus on cemeteries and memorials to the missing, meant that the students largely framed their

\footnotetext{
${ }^{11}$ Focus group 1, 2015. Similar sentiments were also expressed in Focus group 3, 2017.

${ }^{12}$ Free-text comment in post-tour survey, 2017.
} 
experiences within notions of loss and tragedy. Another introductory DVD, A Debt of Honour on the history and work of the Commonwealth War Graves Commission (CWGC), was shown as the coaches departed Calais for Ypres on the first day overseas; it described the horrors of trench warfare and the 'appalling destruction to human life' accompanied by a haunting soundtrack composed by Peter Skellern, setting the tone for much of what the students were about to see. In 2015, a Year 10 student was visibly moved after walking around In Flanders Fields museum at the Cloth Hall in Ypres. She described how emotional she felt after hearing the personal stories of those who survived; 'with their mental scars and aftershocks maybe it's worse than being dead because at least when you're dead the pain has stopped'. At Lijssenthoek cemetery - the second largest CWGC cemetery in Belgium - a Year 6 student commented: 'I didn't realise so many died' before concluding that he would not want to fight for his country because of the risk of being killed. ${ }^{13}$ After witnessing the Last Post ceremony at Menin Gate a number of students felt the need to voice their frustration that Britain only commemorated its First World War dead once a year (in November), rather than every evening as they did in Belgium. Inversely, the tour experience had led them to be openly critical of British commemorative practices for not being sufficiently patriotic.

\footnotetext{
Almost $79 \%$ of survey respondents in 2017 believed the tours had helped them 'understand why the First World War was called a world war' enabled by visits to sites such as NeuveChapelle Indian Memorial in France and/or the Indian Forces Memorial on the ramparts of the south side of the Menin Gate. A full morning was spent at Langemark German cemetery, north of Ypres, Belgium where more than 44,000 German soldiers are buried in multiple occupancy and mass graves. This prompted some students to try and 'see it from the other

${ }^{13}$ Interviews during observational tour, 2015.
} 
side' and appreciate that all soldiers 'were fighting for the same reasons'. ${ }^{14}$ Through a series of reflective activities prompted by 'profile cards' detailing the pre-war and wartime lives of individuals buried in the cemetery the students were able to contrast the more sombre and austere architecture at Langemark with the triumphant memorials and individualised headstones/name boards meticulously maintained by the CWGC. Students contrasted how victorious and defeated belligerents commemorate the First World War noting the freedom Britain had to 'glorify' its military dead. ${ }^{15}$ A Year 12 pupil saw the significance of the Last Post ceremony at Menin Gate being its international nature bringing nations together. Conversely, a Year 10 and Year 12 pupil both thought the ceremony was 'maybe too British?' owing to the domineering lion (a symbol of both Britain and Flanders) lying on top of the gate and the presence of the British Ambassador, uniformed British soldiers and English-language engravings. ${ }^{16}$ A Year 9 student thought the tour could have done more to place emphasis on 'the different countries involved and the different allies and things like that about the different countries.' The visit to Langemark, in her opinion, was excellent but insufficient. ${ }^{17}$

Overall, the students responded ambiguously and in sometimes contradictory ways to aspects of the tour which confronted them with issues relating to the necessity of the war and Britain's position in a historic global conflict. As the 2017 elicitation task on the Battle of the Somme indicated, a large number of students were willing to consider the act of war as futile, even if those involved in its execution were heroes (as discussed below). Some even expressed internationalist ideals that exonerated individual nations or representatives of their armies. Yet despite an awareness that war is unpleasant and undesirable, there was little

\footnotetext{
${ }^{14}$ Overheard conversation between teacher and pupils, observational tour, 2017.

${ }^{15}$ Interviews during observational tour, 2016.

${ }^{16}$ Interviews during observational tour, 2015.

${ }^{17}$ Focus group 5, 2017.
} 
empirical evidence to suggest that these young people were being encouraged, within the confines of the tour, to ask questions about whether the British military should serve the nation or 'police' the world for the common good. The narratives within the tour assumed 'that above all we live in a world of threat and risk, of enemies and allies, and of nation and state rather than global and human interests as operative values' (Lutz, 2009: 25). As Lutz (2009) and McSorley (2014) observe, people rarely articulate militarism explicitly or in a nationalistic way but that does not mean that their practices do not facilitate nationalistic and geopolitical ideas such that war is inevitable and having enemies is a natural position.

\section{Violence made visible?}

In many ways there was a strong disjuncture between the violence that characterised the First World War and the educational content of the FWWCBTP. One regular soldier, participating in a tour as a coach chaperone in 2015 , felt torn between the realities of his job and the audience he had enlisted to support on the tours: 'the kids are asking me "what does the army do?" and I want to say "violence, killing people. In the event politics fails, we go in to kill, protect Britain and its interests. Sometimes we build schools, wells, but we also blow things up." ${ }^{18}$ For another regular, in 2016, the number one question the young people asked him was 'how many people have you killed?' ${ }^{19}$ His response was to draw their attention to the multiple roles played by the British army including disaster relief and supporting the police. Some teachers, particularly those accompanying younger pupils, also faced difficulties explaining the ramifications of mass industrialised warfare in an age-appropriate manner. In 2015, at Thiepval Memorial to the more than 72,300 missing British and South African soldiers of the Somme, a Year 6 pupil seemed confused about where their bodies were. His teacher explained that they were 'lost in the fields' around where they were standing and

\footnotetext{
${ }^{18}$ Interview during observational tour, 2015.

${ }^{19}$ Interview during observational tour, 2016.
} 
'couldn't be brought home' without detailing the pulverising effect of artillery bombardment. The beautiful and neatly kept cemeteries of the CWGC had obscured the harsh realities of one of the bloodiest moments in twentieth century history.

One of the main roles of the serving army personnel was to help run the object handling sessions that featured twice in the tour, alongside the GBG, many of whom had themselves served in the armed forces. On the first night of the tour, a selection of predominately military items relating to the First World War were explored. Unsurprisingly, with its emphasis on tactile learning, free discussion and independent thinking, this was one of the most popular aspects of the tour for the students. The larger items (rifle and wire cutters) were particularly popular (described by one GBG in 2017 as 'the big tourist attraction'), as was the helmet, which the young people tried on and captured as 'selfies' on their smartphones. As one Year 9 pupil exclaimed, in 2017, as he pointed a First World War era Lewis gun at the classmate taking his photo: 'I love the way we learn about such a sad thing in such a cheery way - it's great!' ${ }^{20}$ There were attempts to alert the students to the purpose of these items (to kill others/protect yourself from being killed) supported by the serving army personnel who shared stories of shrapnel injuries and leading bayonet charges during the 2003 invasion of Iraq. ${ }^{21}$ But the light-hearted atmosphere was quickly restored when the session leaders returned to encouraging photos or joked about bayonets being good tinopeners.

As Rech (2019) has demonstrated in his work on material cultures of British military recruitment, the 'static', in situ stuff in these object handling sessions highlight 'the

\footnotetext{
${ }^{20}$ Overheard during observation, 2017.

${ }^{21}$ Observed during object handling sessions, 2016 and 2017.
} 
determinacy of immediate space' which acts 'to decontextualize objects - to remove them from spaces of battle - in order that a range of ethical questions about their use might be avoided' while simultaneously 're-plac[ing] objects in the imagined landscapes of Western military endeavour' (Rech, 2019: 12). On the third night of the tour, the GBG and army personnel, supported by UCL IoE staff, ran a session contrasting First World War era and present-day equipment utilised by the British army. While this helped students understand historical change and continuities it also had a tendency, during the observations undertaken, to descend into play with students and teachers trying on uniform, painting their faces with camouflage cream (2015), undertaking a 'gas mask' relay race (2016) and the distribution of army branded 'goodies' like pencils and glow sticks $(2017)^{22}$, which bear a troubling similarity to the 'thing-ness' of contemporary recruiting and remembrance. Here objects such as Help for Heroes bracelets, poppies and free pens, lanyards and keyrings distributed at outdoor military recruitment events - fold militarism and geopolitical power into everyday habits and routines animating certain narratives about warfare that obscure violence and bloodshed (Basham, 2016; Rech, 2019).

The circumnavigation of violence within some aspects of the tour risked its effects being normalized and morally neutralized (Bourke, 2014: 6). However, the sheer scale of the cemeteries and memorials visited, as well as the tour's emphasis on every headstone telling the story of an individual and their family impacted by war (Bendry, 2017), ensured that the students could not interpret war as something 'fun' and without consequence, even if they did not go into the precise, and gory, details of how combatants were injured and killed. The cemeteries depict, in stark and sombre detail, the human cost of war (Miley and Read, 2017).

\footnotetext{
${ }^{22}$ The latter three were described by the UCL IoE team as inappropriate anomalies, rather than regular fixtures, that were stopped each tour season. Email correspondence between FWWCBTP Programme Director and author, 19 October 2017.
} 
Both the 2015 and 2017 survey results indicated that 'scale of loss' was the second key piece of information learnt about the First World War after 'major battles'. Students described feeling predominately 'surprised' and 'sad' when they saw the cemeteries for the first time. ${ }^{23}$ As one Year 9 student commented after visiting Tyne Cot cemetery: 'Wow. It's one thing seeing 12,000 written in a book, but it's another thing seeing 12,000 headstones' ${ }^{24}$ In an effort to make the unimaginable number of losses intelligible, students were assigned a soldier, with some association to their locality, killed during the First World War and buried/listed at Tyne Cot or Thiepval memorial. They researched his story using internet resources before being encouraged to lay a wooden cross - provided by the tour in exchange for a small donation to the Royal British Legion (RBL) - when they found 'their' soldier's headstone/engraved name. Two Year 12 pupils were visibly overwhelmed at finding the headstone of the soldier they had researched: 'It's really tough actually. I feel a huge sense of closure'; 'It's just really sad. We've heard about his name... and now we're here and it says he's 19...his brother isn't here, he's in Thiepval. ${ }^{25}$ Arguably, in comparison to other statemanaged sites of memorialisation on sacred land, such as Ground Zero in New York City, the bodies - at least in the form of their names - are visible, thwarting any attempt by the state to conceal the link between its security needs and the cost to human life (Auchter, 2015).

\section{Fallen soldiers}

While the FWWCBTP enabled student participants to critically reflect on whether the First World War was 'just', primarily by confronting them with the human cost of war, the tours must be understood on a continuum of British ritualised remembrance that emerged during the war itself. Such practices 'elevated the war to a sacred event through its concentration on the sacrifice of the fallen' and thus denied people any opportunity to criticise the war

\footnotetext{
${ }^{23}$ Survey results, 2015 and 2017.

${ }^{24}$ Interview during observational tour, 2015.

${ }^{25}$ Interview during observational tour, 2017.
} 
(Bushaway, 1992: 137; Lloyd, 1998: 173). As Basham (2016) has explored in relation to recent iterations of the RBL's Annual Poppy Appeal, mourning and remembrance of past wars has been separated from military violence, particularly linguistically, with the emphasis on 'fallen' soldiers. The tours are weaved together by a series of acts of remembrance interpreting war deaths as noble sacrifices and burial sites and memorials as sacred places worthy of respect and veneration. While many of the students were familiar with remembrance practices from Remembrance Day services at their schools every November, the tours confirmed key behaviours associated with contemporary remembrance over an intense four-day period. ${ }^{26}$ Students were encouraged to lay wooden poppies at the name/headstone of the local soldier they were assigned to research; selected to lay a wreath at the Last Post ceremony at the Menin Gate; encouraged to donate to RBL collection boxes that were passed around the coach at the end of the tour; and, across all observations, increasing numbers of students were observed purchasing and wearing red poppy pin badges. The students described their behaviour and responses to such acts of remembrance in language that drew heavily on traditional tropes of sacrifice, respect, pride and gratitude. For two Year 12 and 13 pupils, the ceremony at Menin Gate was significant because it was 'an opportunity to remember the sacrifice and the lives lost so we could be free'. ${ }^{27}$ A Year 10 pupil who was selected to lay a wreath during the ceremony understood the ritual in terms of an unquestionable duty to atone for a past debt: 'Hundreds of thousands of people died for us so we could live our way of life. We've got to remember because if we forget then it's like we don't care. We owe them everything.' A Year 11 student wore a red poppy 'as a badge of respect' to the 'numbers who died fighting for democracy'. One Year 10 pupil, moved by the number of headstones in a single cemetery, was consciously avoiding feeling 'too sad'

\footnotetext{
${ }^{26}$ In $2015,57.8 \%$ of survey respondents had participated in a remembrance ceremony in the UK before the tour. In 2017 this figure decreased slightly to $54.6 \%$.

${ }^{27}$ Interview during observational tour, 2016.
} 
because 'we're here to remember and ... be grateful'. Another pupil, also Year 10, felt proud laying a wreath at the Menin Gate because it was a way of saying thank you to those who had served. ${ }^{28}$

Each tour ended with a final whole-group ceremony at Tyne Cot cemetery where students were invited to reflect on the final enquiry question (should we still remember 100 years on?) before listening, often with heads bowed, to the 'Ode of Remembrance' from Laurence Binyon's poem 'For the Fallen'. It was an experience that a number of students found very emotional and some were moved to tears. ${ }^{29}$ In 2015 , explicit links were made between the sacrifice of soldiers in the First World Wars and those serving in current conflicts through a deeply personal reflection by one of the UCL IoE team on the death of a Royal Marine in Afghanistan in June 2010 who had studied at their former school. Students stood silently around the Cross of Sacrifice, serving soldiers in their midst, as they were told: 'soldiers are still today going off and ... making the same sacrifices' before being asked 'time has passed and now it's for you to decide are they still important'.$^{30}$ The 'past' became affirmation of the 'present' (Basham, 2016) potentially legitimising armed conflicts in Iraq and Afghanistan that bear little resemblance to the conflict of 1914 to 1918 (Danilova, 2015; Jenkings et al, 2012) and closing down the opportunity to query whether remembrance deserves the attention it receives in contemporary British society (Pennell, 2018).

As well as accompanying students in the formal wreath-laying ceremony at the Menin Gate ceremony, serving soldiers were called upon throughout the tours to offer their insights into strategy, tactics and equipment, often leading activities, answering questions and engaging

\footnotetext{
${ }^{28}$ Interviews during observational tour, 2015.

${ }^{29}$ Focus group 1, 2017.

${ }^{30}$ Observed during tour, 2015.
} 
the students in conversation thus assuming a position of authority. Their presence was a highlight for the majority of participating students, providing, in their opinion, a unique insight into what being a soldier involves. In 2017, 'meeting and talking with army personnel' was the second most popular aspect of the tour for survey respondents. For a Year 10 pupil this was because they helped bridge 100 years of history: 'I like the modern-day soldiers being there in general because I thought that's really cool because they're telling their experiences now and they can relate it back there [the First World War]. ${ }^{31}$ For others, their presence helped to break-down civil-military barriers, allowing the students to understand that soldiers were also human too. ${ }^{32}$ Some students thought the soldiers added an element of fun to the programme, particularly the equipment handling sessions which were 'so interactive and we got lots of free stuff like the glow sticks'. ${ }^{33}$ Focus group discussions and free-text comments in the surveys suggested some students wanted the soldiers to have been more involved in the tours. ${ }^{34}$

As with other soldier-centred remembrance practices, these interactions with serving army personnel manifested feelings of 'hero-ification' (Kelly, 2012). A number of students referenced how they had a new-found respect for the bravery and heroism of present-day soldiers as a result of the tour. ${ }^{35}$ First World War soldiers were characterised by the students as duped 'innocents', a tendency evident across broader British society (McCartney, 2014). ${ }^{36}$ Some students were capable of thinking about these issues critically. One Year 9 pupil reflected on the moral complexity of being a soldier: 'they save their country but at the same time they kill another [person]...they've saved someone's life but, in turn, they've ended

\footnotetext{
${ }^{31}$ Focus groups 1 and 4, 2017.

${ }^{32}$ Focus group 2, 2017.

${ }^{33}$ Interview during observational tour, 2017.

${ }^{34}$ Focus group 4, 2017.

${ }^{35}$ Focus groups 1 and 2, 2017.

${ }^{36}$ Focus group 2, 2017.
} 
someone else's' ${ }^{37}$ In 2015, a Year 11 pupil felt the presence of military personnel restricted their ability to ask questions. For them, no one was going to respond to the enquiry question 'should we remember' in the negative if a serving soldier was within earshot. ${ }^{38}$ But these critical interjections were limited. The majority of students agreed that raising an objection to remembrance or criticising the soldier-dead was inappropriate and disrespectful. The analogy used by one Year 12 student was: 'walking into a church and you know saying that you love the devil and you hate god and everything. ${ }^{39}$ Overall, the tours dissuaded students from questioning 'the violence done to and perpetrated by' soldiers (Basham, 2016: 892).

\section{Conclusion}

The FWWCBTP was the most significant youth-centred activity funded by the UK government during the centenary of the First World War. Influenced by scholars in Critical Military Studies and Military Geography, this article has taken a moment of intense focus on young people and war remembrance to see what it reveals about processes of militarisation in the global north. Focusing on Enloe's core tenets of militarism subtlety present within the tour content - war is necessary and purposeful, with having enemies being a natural condition; violence is normal; the soldier is to be glorified - it has revealed that student understandings of these ideas are complex and fluid. As studies into youth responses to Anzac Day in Australia and New Zealand have shown, the young participants of the FWWCBTP were capable of holding a range of views simultaneously that were not confined by the restrictive binaries of militaristic/anti-militaristic, pro/anti-war, nationalist/internationalist, patriotic/unpatriotic (Davison, 2003; McKay, 2013; Scates, 2006; Sheehan and Davison, 2017). While students came away from the tours with a largely British understanding of the First World War and the major battles fought by the British army, this

\footnotetext{
${ }^{37}$ Focus group 2, 2017.

${ }^{38}$ Focus group 1, 2015.

${ }^{39}$ Focus group 2, 2015.
} 
was framed within a strong awareness of the tragic cost of the war leading many students to question whether the war was worth fighting. During the tours, the students were confronted with both the implements and implications of violence. Certainly, the tours raise broader questions about the ethics of 'discomforting pedagogies' whereby educators and students alike move outside their 'comfort zones' and confront the unsettling feelings that may emerge (Zembylas and McGlynn, 2010). But it would be false to claim that the students were not being exposed to what violence in war means, even if this was sometimes achieved through playful techniques such as object handling. While not denying the tours were in large part a series of acts of remembrance, which in themselves are both deeply political and militarised, the fact that they took place against the backdrop of cemeteries and memorials enabled the students to return home more aware of the destructive consequences of war for all nationalities involved.

However, the involvement of serving army personnel in the tours did serve to project the armed forces as legitimate and worthy of respect (Wells, 2014). Students struggled to contemplate not taking 'their expected place in the ceremonial order' or even challenging 'the order itself' through fear that they would be dismissed and derided by their peers (Kelly, 2012: 735). In light of research by Gee (2007) and Sangster (2013), the engagement of the armed forces with young people via the FWWCBTP could be understood as part of a wider recruitment strategy present before the centenary. The UCL IoE team were attuned to this risk and explicit in their oversight of the MoD that 'there was to be no recruitment element ...no literature handed out ...nothing there that could be deemed as the Army looking to recruit young people' ${ }^{40}$ Instead, this aspect of the tours should be understood as part of a trend of the rehabilitation of the military in the aftermath of the Iraq War (Jenkings et al,

\footnotetext{
${ }^{40}$ Interview with FWWCBTP Programme Director, 23 May 2019.
} 
2012). As an exercise in promoting positive civilian-military relations, the tours were very successful. They also raise difficult questions about how young people can be encouraged to critique the 'figure of the soldier' without demeaning the value of the individual human being (Jenkings et al, 2012: 361).

Perhaps most troublingly, the tours did little to challenge young people's assumptions that war is inevitable. Students frequently attested to the tours' value being in keeping the memory of the First World War alive to ensure 'lessons are learned' and societies 'never forget'. However, the presence of serving army personnel who had seen action in recent conflicts was evidence that these phrases were inane. With remembrance the pivot axis of the tours, in a context of a diminution of peace education more generally (Cook, 2008), the students' focus remained on their individual responses to violence rather than the structural causes of violence (Bourke, 2014); politics was separated from remembrance (Danilova, 2015). One Year 12 student said she 'felt really sad because wars just keep going and will never end.' Her classmate interjected: 'if I ruled the world I'd make sure everyone was friends [laughs] but I know that will never happen. ${ }^{41}$ A Year 10 pupil admitted: 'Remembrance isn't working ... we have all the evidence there and we know that it's tragic and futile but we still do it'. ${ }^{42}$

Finally, this article has highlighted the ways in which children and young people are inherent to discourses and practices of remembrance, and not simply standing on the periphery of a cultural and political practice that would continue regardless of their participation. This is particularly evident in the context of the First World War centenary; the absence of living

\footnotetext{
${ }^{41}$ Interviews during observational tour, 2016.

${ }^{42}$ Focus group 1, 2017.
} 
veterans meant it was young people who had 'to bear the burden of memory in order to pass it onto subsequent generations' (Pennell, 2016: 38). Complementing work by Basham (2016) and others - who have demonstrated that particular imaginaries of the family, and masculinities and femininities, undergird practices of remembrance - this article demands a more ambitious rendering of the figure of the child, one that acknowledges the political utility of conceptions of 'youthfulness' and 'innocence' in contemporary remembrance discourse and that understands contemporary remembrance practices as an attempt to re-cast 'aged', historic and temporally distant memorial spaces as multi-generational in order to retain their meaning and relevance. Thus commemorative initiatives, such as the FWWCBTP, are not only part of a portfolio of 'mundane embodied practices and idioms' that enable 'a broad and subtle form of militarism' to become 'something not explicitly thought but simply felt to be habitually right...from an early age' (McSorley, 2014: 119), but they are inherently dependent on children and young people - and what they are imagined to represent. 


\section{References}

Auchter J (2015) The Politics of Haunting and Memory in International Relations. Abingdon: Routledge.

Ashplant TG, Dawson G and Roper M (2000) The Politics of War Memory and Commemoration. London: Routledge.

Basham VM, Belkin A and Gifkins J (2015) What is Critical Military Studies? Critical Military Studies 1(1): 1 - 2.

Basham VM (2016) Gender, race, militarism and remembrance: the everyday geopolitics of the poppy. Gender, Place \& Culture: A Journal of Feminist Geography 23(6): 883 - 96.

Beaumont J (2015) The politics of memory: Commemorating the centenary of the First World War. Australian Journal of Political Science 50(3): 529 - 35.

Beier JM (2011) Introduction. In: The Militarization of Childhood: Thinking Beyond the Global South. Basingstoke: Palgrave Macmillan, pp.1 - 15.

Bendry S (February 2017) Learning beyond the battlefield. Leader: The Magazine for School and College Leaders. Available

at http://www.leadermagazine.co.uk/articles/learning beyond the battlefield//accessed 12 July 2019).

Benwell MC and Hopkins P (2016) Introducing Children's and Young People's Critical Geopolitics. In: Benwell MC and Hopkins P (eds) Children, Young People and Critical Geopolitics. Abingdon: Routledge, pp.1 - 27.

Bernazzoli RM and Flint C (2009) Power, Place and Militarism: Toward a Comparative Geographic Analysis of Militarization. Geography Compass 3(1): 393 - 411.

Bernhard R (2019) Using mixed methods to capture complexity in an empirical 
project about teachers' beliefs and history education in Austria. History Education Research Journal 16(1): 63-73.

Bourke J (2014) Wounding the World: How Military Violence and War-Play Invade Our Lives. London: Virago Press.

Bushaway B (1992) Name Upon Name: The Great War and Remembrance. In: Porter R (ed) The Myths of the English. Cambridge: Polity Press, pp.136 - 67.

Carter S, Kirby P and Woodyer T (2016) Lucic - or Playful - Geopolitics. In Benwell MC and Hopkins P (eds) Children, Young People and Critical Geopolitics. Abingdon: Routledge, pp.61-89.

Cook SA (2008) Give Peace a Chance: The Diminution of Peace Education in Global Education in the United States, United Kingdom, and Canada. Canadian Journal of Education 31(4): 889 - 913.

Danilova N (2015) The Politics of War Commemoration in the UK and Russia. Basingstoke: Palgrave Macmillan.

Davison G (2003) The Habits of Commemoration and the Revival of Anzac Day. Australian Cultural History 22: $73-82$.

Doucet MG (2005) Child's play: The political imaginary of international relations and contemporary popular children's films. Global Society 19(3): 289 - 306.

Edkins J (2003) The Rush to Memory and the Rhetoric of War. Journal of Political and Military Sociology 31(2): 231 - 51.

Enloe C (1983) Does khaki become you? The militarisation of women's lives. London: Pluto Press. 
Enloe C (2000) Maneuvers: The International Politics of Militarizing Women's Lives.

Berkley CA: University of California Press.

Enloe C (2004) The Curious Feminist: searching for women in a new age of empire.

Berkeley, CA: University of California Press.

Enloe C (2007) Globalization \& militarism: feminists make the link. Lanham, MD: Rowman \& Littlefield.

Foley RT (2014) Op REFLECT: What Can We Learn from the First World War? Available at https://defenceindepth.co/2014/11/10/op-reflect-what-can-we-learn-from-the-first-world-

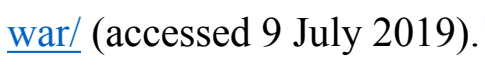

Gee D (2007) Informed Choice? Armed forces recruitment practice in the United Kingdom. York: Joseph Rowntree Charitable Trust.

Gillis JR (ed) (1994) Commemorations: The Politics of National Identity. Princeton, NJ: Princeton University Press.

Hopkins PE (2010) Young People, Place and Identity. Routledge: London.

Hörschelmann K (2016) Crossing Points: Contesting Militarism in the Spaces of Children's Everyday Lives in Britain and Germany. In: Benwell MC and Hopkins P (eds) Children, Young People and Critical Geopolitics. Abingdon: Routledge, pp.29 - 44.

Hyde A (2016) The present tense of Afghanistan: accounting for space, time and gender in processes of militarisation. Gender, Place \& Culture: A Journal of Feminist Geography 23(6): $857-68$.

Gor H (2003) Education for war in Israel: preparing children to accept war as a natural factor of life. In: Saltman KJ and Gabbard DA (eds) Education as Enforcement: The Militarisation and Corporatization of Schools. New York NY: Routledge Falmer, pp.177 - 88. 
Hutchinson J (2007) Warfare, Remembrance and National Identity. In Leoussi AS and Grosby S (eds) Nationalism and Ethnosymbolism: History, Culture and Ethnicity in the Formation of Nations. Edinburgh: Edinburgh University Press, pp.42 - 52.

Jenkings KN, Megoran N, Woodward R and Bos D (2012) Wootton Bassett and the political spaces of remembrance and mourning. Area 44(3): $356-63$.

Kelly J (2012) Popular Culture, Sport and the 'Hero'-fication of British Militarism. Sociology 47(4): $722-38$.

Lloyd DW (1998) Battlefield Tourism: Pilgrimage and the Commemoration of the Great War in Britain, Australia and Canada, 1919-1939. Oxford: Berg.

Lutz C (2009) The military normal. In: Network of Concerned Anthropologists (eds) The Counter-Counterinsurgency Manual. Chicago IL: Prickly Paradigm Press, pp.23 - 37.

McCartney H (2014) The First World War soldier and his contemporary image in Britain. International Affairs 90(2): 299 - 315.

McSorley, K (2014) Towards an embodied sociology of war. The Sociological Review 62:S2: $107-28$.

Macdonald F (2008) Space and the Atom: On the Popular Geopolitics of Cold War Rocketry. Geopolitics 13(4): $611-34$.

McKay J (2013) A Critique of the Militarisation of Australian History and Culture Thesis: The Case of Anzac Battlefield Tourism. Journal of Multidisciplinary International Studies 10(1): $1-25$.

Miley F and Read A (2017) Their name liveth for evermore: Accounting for the human cost of war. In: $9^{\text {th }}$ Accounting History International Conference, Verona, Italy, 6 - 8 September 2017. Available at 
https://www.researchgate.net/publication/323836116 Their name liveth for evermore Acc ounting_for_the human_cost_of_war (accessed 14 July 2019).

Mosse GL (1990) Fallen Soldiers: Reshaping the Memory of the World Wars. Oxford: Oxford University Press.

Mycock A (2014) The First World War Centenary in the UK: “A Truly National Commemoration"? The Round Table: The Commonwealth Journal of International Affairs 103(2): $153-62$.

Pennell C (2016) Learning Lessons from War? Inclusions and Exclusions in Teaching First World War History in English Secondary Schools. History and Memory 28(1): 36 - 71.

Pennell C (2018) Taught to Remember? British Youth and First World War Centenary Battlefield Tours. Cultural Trends 27(2): 83 - 98.

Pennell C and Sheehan M (2020) But what do they really think? Methodological challenges of investigating young people's perspectives of war remembrance. History Education Research Journal 17(1): forthcoming.

Power M (2007) Digitized Virtuosity: Video War Games and Post 9/11 Cyber-Deterrence. Security Dialogue 38(2): $271-88$.

Reagan PM (1994) War toys, war movies and the militarization of the United States, 1900 1985. Journal of Peace Research 31(1): 45 - 58.

Rech MF (2014) Be Part of the Story: A popular geopolitics of war comics aesthetics and Royal Air Force recruitment. Political Geography 39: 36 - 47.

Rech MF (2016) Children, Young People and the Everyday Geopolitics of British Military Recruitment. In: Benwell MC and Hopkins P (eds) Children, Young People and Critical Geopolitics. Abingdon: Routledge, pp.45 - 60 . 
Rech MF (2019) Ephemera(1) Geopolitics: The Material Cultures of British Military Recruitment. Geopolitics (published online 11 February 2019): 1 - 24.

Reeves A (2018) Auto-ethnography and the Study of Affect and Emotion in World Politics: Investigating Security Discourses at London's Imperial War Museum. In: Clément M and Sangar E (eds) Researching Emotions in International Relations: Methodological Perspectives on the Emotional Turn. Cham: Palgrave Macmillan, pp.103 - 27.

Riley M (2000) Into the Key Stage 3 history garden: choosing and planting your enquiry questions. Teaching History 99: 8 - 13 .

Sangster E (2013) The military's influence in UK education. In: Everett O (ed) Sowing Seeds: The Militarisation of Youth and How to Counter It. London: War Resisters' International, pp.86-93.

Scates B (2006) Return to Gallipoli: Walking the Battlefields of the Great War. Cambridge: Melbourne University Press.

Shaw IGR (2010) Playing war. Social \& Cultural Geography 11(8): 789 - 803.

Shaw M (1991) Post-Military Society: Militarism, Demilitarization and War at the End of the Twentieth Century. Cambridge: Polity Press.

Sheehan M and Davison M (2017) 'We need to remember they died for us': How young people in New Zealand make meaning of war remembrance and commemoration of the First World War. London Review of Education 15(20), 259 - 71.

Sheffield G (2001; 2018) Forgotten Victory: The First World War Myths and Realities. London: Headline ( $1^{\text {st }}$ edition).

Shipman T (2 January 2014). Michael Gove blasts 'Blackadder myths' about the First World War spread by television sit-coms and left-wing academics'. Daily Mail. Available 
at http://www.dailymail.co.uk/news/article-2532923/Michael-Gove-blasts-Blackaddermyths-First-World-War-spread-television-sit-coms-left-wing-academics.html (accessed 12 July 2019).

Solomon I and Denov M (2010) Militarised Bodies: The Global Militarisation of Children's Lives. In: Hörschelmann K and Colls R (eds) Contested Bodies of Childhood and Youth. Basingstoke: Palgrave Macmillan, pp.163 - 77.

Stern P (1995) Why do people sacrifice for their nations? Political Psychology 16(2): 217 35.

Wells K (2014) Marching to be somebody: a governmentality analysis of online cadet recruitment. Children's Geographies 12(3): 339 - 53.

Winter J (2006) Remembering the Great War: The Great War between Memory and History in the Twentieth Century. New Haven CT: Yale University Press.

Woodward R (2004) Military Geographies. Oxford: Blackwell.

Zembylas M and McGlynn C (2010) Discomforting pedagogies: emotional tensions, ethical dilemmas and transformative possibilities. British Educational Research Journal 38(1): 1 19. 